\title{
Cell equalisation circuits: A Review
}

\author{
Jonathan Carter*, Zhong Fan, Jun Cao \\ ${ }^{a}$ Keele University, Staffordshire, UK, ST5 5BG
}

\begin{abstract}
Large Li-ion battery packs are an enabling technology for electric vehicles, smart homes and the smart grid. Keeping the individual cells that make up the battery pack balanced reduces the loss of capacity over time and reduces the chances of damaging the pack by over charging/discharging cells. This paper presents a review of the basic charge equalisation circuits categorised as capacitor, inductor or transformer based. The paper highlights improvements and variations made to these basic circuits by researchers and provides a general comparison. The paper proceeds to discuss the difficulties in directly comparing performance of different CECs (charge equalisation circuit) and the ambiguity of the industrial requirements of a CEC. Finally the paper presents possible areas of research to further improve the charge equalisation process.

Keywords: Battery balancing, Cell equalisation, State of charge (SOC), Cell equalisation circuit (CEC)
\end{abstract}

*I am corresponding author

Email addresses: j.h.carter@keele.ac.uk (Jonathan Carter), z.fan@keele.ac.uk (Zhong Fan), j.cao@keele.ac.uk (Jun Cao) 


\section{Introduction}

\subsection{Reason for development}

As the world moves towards the decarbonisation of the power grid, industry and transport due to environmental concerns, Li-ion battery packs have emerged as a critical early technology. They are enabling the electrification of transport as energy storage in electric vehicles and the move towards a distributed smart grid both as local energy storage for smart homes and large grid storage. Modern battery packs are made up of hundreds or thousands of individual cells connected in different configurations of series and parallel in order to provide the necessary voltage (number of series connections) and amp-hours (number of parallel connections). However, variations in the cells caused by the manufacturing process, charge discharge cycles (lifetime of the cell) and the temperature during operation means that the series connected cells can become unbalanced in the amount of charge they are storing $[1,2]$. This leads to issues such as:

- Undercharging, this is when a number of cells within the string is left below its maximum capacity. Although not dangerous it limits the overall capacity of the battery pack resulting in reduced EV driving range.

- Overcharging [3], very dangerous as cells forced to charge past their safety threshold results in large amounts of thermal energy to be produced which could result in chemical explosion. This would cause irreparable damage to the battery pack and car.

- Under discharging, caused by a number of cells that have lower capacity than the others in the string. When these cells reach their lower safety 
threshold the battery pack will believe it is fully discharged. The cells that remain with charge cannot use this energy and therefore overall capacity of the battery pack is lost.

- Over discharging, if the lower safety threshold a a cell is ignored the cell can become over discharged. In this mechanism cells exhibit thermal instability, permanent loss of capacity and possible short circuit due to the copper anode migrating across the cell to the cathode $[4,5]$.

To avoid these problems, regular cell balancing is required. The perfect solution would be described as an equalisation circuit that has the following desirable characteristics:

- Cheap.

- Scalable for very large or differently configured battery packs.

- Simple control method and implementation.

- Low switch stress.

- High efficiency with low thermal production.

- High thermal resilience (able to work in high temperature environments).

- Bi-directional, able to equalise while charging or discharging.

- High effectiveness, able to balance a large number of cells with minimal variation.

- High speed, able to balance cells very quickly. 
- Low circuit volume (doesn't take up a lot of space).

Not one circuit offers all of these attributes, although there are many circuits that offer an interesting balance.

This paper looks at the current solutions suggested in research for balancing cells within a Li-ion battery pack. The rest of the paper is organised as follows: Charge equalisation circuits split into two main categories, passive and active cell balancing methods. Section 2 discusses the passive equalisation which is simple with low efficacy. Section 3 is the main section where all the basic types of active equalisation are discussed. They are categorised into: 3.1 capacitor based , 3.2 inductor based and 3.3 transformer based solutions . A comparison and general discussion then follows in section 4 with some recommendations about how research should be presented to allowing meaningful comparison. Finally, areas of future research are presented in section 5 .

\section{Passive equalisation}

Passive equalisation relies on resistance to dissipate excess energy from the high voltage cells within a series string [6]. This form of equalisation is most popular in industry thanks to the low cost of components and simple control schemes [7]. Traditional passive equalisation either uses a fixed resistor or a switched resistor. In the fixed resistor scheme there is a continuous bypass current that limits the voltages of the cells. This cannot be used with Li-ion battery packs as cells can get overcharged. This is not a problem for Lead acid and Nickel based chemistries [8]. Switched resistor schemes target the cells with the highest voltages. Once identified, a resistor is switched in and the cell provides a current through the resistor. Energy is dissipated until the cell is balanced with the rest of the string 
[9].

Problems include very long equalisation times, excessive heat produced due to the energy dissipation and low efficiency. Equalisation current must be kept very low because of power losses and thermal management, which leads to the very slow equalisation times [10].

Recently $\mathrm{Xu}$ [7] presents an adaptation to the switched resistor circuit by eliminating the resistor. The circuit instead uses cleaver control of the MOSFET driver circuit to control equalisation currents, essentially turning the MOSFET into a variable resistor.

\section{Active equalisation}

Active equalisation deals with the transfer of energy rather than the dissipation of it and is much more efficient than passive equalisation [11]. In general, energy from an overcharged cell or cells is stored temporarily in a capacitor, an inductor or a transformer, and then discharged into an uncharged cell or cells [12]. There are some circuits that work on a shuttling (energy is automatically transferred to and from adjacent cells) basis where there is no need for any complicated control or voltage sensing as the charge equalisation circuit continually switches between two states allowing adjacent cells to be balanced. This method is know as adjacent cell to cell (AC2C). The equalisation speed of this method is dependent on the number of the batteries within the string and position of the unbalanced cells within the string (at the ends or in the middle). In directed cell to cell (DC2C) methods voltage sensing is required and a simple control system to order the cells from highest to lowest SOC. Cells are directly targeted to transfer energy from one to another. This method is often quite slow, especially for large strings of series 
connected cells as only one cell can be balanced at a time. Cell to pack methods (C2P) is when an overcharged cell distributes its excess energy to the whole pack (or module). This iterative process continues until the pack is balanced, requiring sensing and a controller to select the overcharged cells. Pack to cell (P2C) takes a small amount of energy from every cell and then uses that energy to charge the lowest energy cell in the string. Just like C2P this is an iterative process. The last category is multi cell to multi cell equalisation (MC2MC). This method again requires sensing and a complex controller, which can select one cell or multiple cells to discharge, storing the energy temporarily. Then can select one or multiple cells to redistributed that energy too [13]. Figure 1 shows the relationships between the different circuit topologies discussed in this paper.

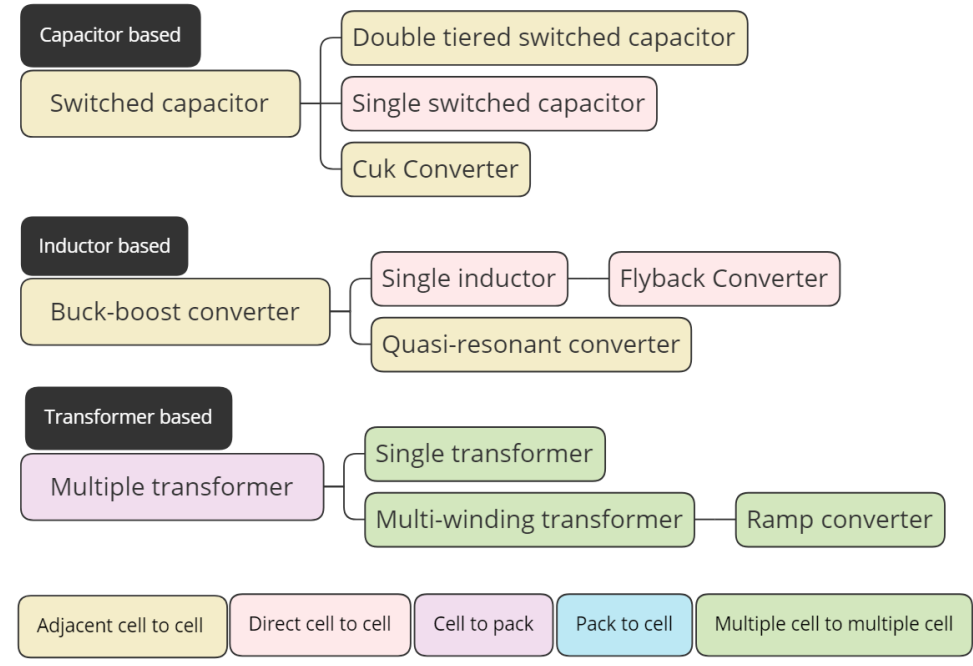

Figure 1: The basic types of active CEC

\subsection{Capacitor based CEC}

\subsubsection{Switched capacitor}

This method is very simple, introduced by Pascual [14] and shown in figure 2 . 


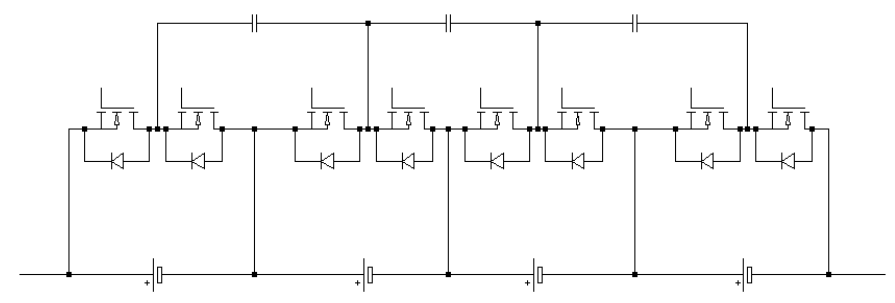

Figure 2: Switched capacitor CEC

The capacitors are constantly switched between adjacent cells. If there is a difference in charge state between the two cells, the capacitor is charged by one cell and then discharged through the adjacent cell, transferring excess charge between the two. As all cells are connected this eventually balances the whole pack.

The advantage is that you don't need complicated control systems nor sensing [14]. Balancing can be achieved while charging or discharging [15]. The architecture is easily extendable for larger battery packs [16].

The main disadvantage is the slow balancing speed, the worst case scenario being that the first cell in the string is unbalanced compared to the last cell string. In this scenario the excess charge would have to be passed through every cell in order for this imbalance to be rectified. This problem is exacerbated by having more cells in the battery pack making scalability an issue [17].

Kim [18] proposed a chain structure to decrease the time taken to achieve balance. In this chain structure, as shown by Kim [18], the first and last cell in the string are linked, creating a chain of cells. This reduces the distance between the worst case scenario unbalanced cells by half. Now the worst case scenario of this topology would be if the first cell and middle cell were unbalanced.

Ye [17] also comments on a more topologies as well as experimentally com- 
paring his proposed structure. Ye further explains that the main advantage of this structure is that balancing time becomes independent of cell number and the initial mismatch distribution of the cell voltages [17].

A mesh capacitor structure is suggested by Shang [19], which achieves any cell to any cell equalisation also eliminating an inherent weakness of the basic switched capacitor system proposed by Pascual. Shang goes on to say that the configuration is easily modularised by connecting the central nodes of the mesh structure together allowing for multiple mesh structures per battery pack, as well as high reliability due to low voltage stress on the MOSFET switches [19].

\subsubsection{Double tiered switched capacitor}

By adding another tier of capacitors, as show in Ye [17], cells that are not directly connected together via a capacitor can now equalise through the second tier. This has the effect of decreasing equalisation time [20]. Equalisation occurs through the same mechanism of charging and discharging capacitors by regular switching. The difference with a single tiered system is, that in the worst case scenario of the upper most cell and the lower most cell being unbalanced there would be half as much switching events needed for balancing to occur [20].

The main disadvantage of this topology is the increased cost of components, size of the circuit in terms of volume and compared to other techniques the balancing speed is still quite slow.

As with the single tiered counterpart variations of the basic circuit have been researched. Fukui [21] looked at a chain structure similar to Kim [18]. This circuit has the same benefits and operation. The upper and lower cells are connected via a capacitance allowing balancing to occur between the two cells, effectively reducing the maximum balancing path by half. 


\subsubsection{Single switched capacitor}

The single switched capacitor works very differently from the previous two capacitor methods discussed so far. In this configuration cells are targeted by a simple control algorithm rather than excess energy being automatically shuttled from cell to cell. A single capacitor configuration is said to be direct cell to cell or time shared. A high SOC cell is then selected by the controller and the capacitor is switched into parallel so the capacitor charges up. A low SOC cell is then selected and switched into parallel with the charged capacitor and energy is transferred from the capacitor to the low SOC cell. An example of a simple single switched capacitor circuit can be seen in figure 3 .

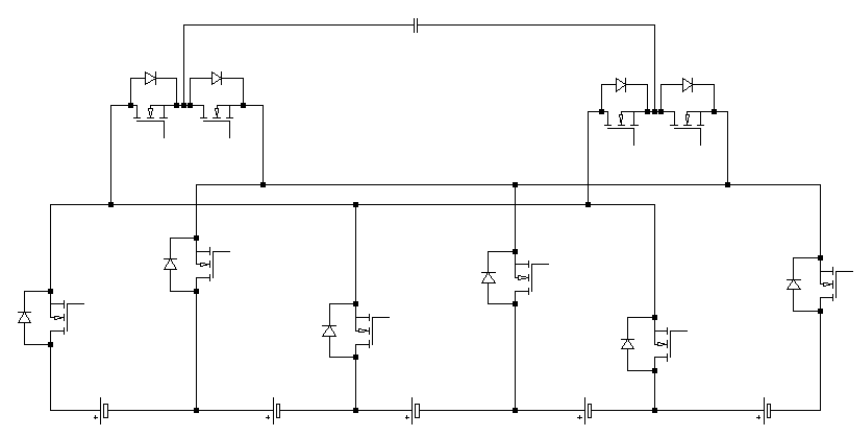

Figure 3: Single switched capacitor CEC

This configuration has the advantage that any cell in the string can be used to balance any other cell in the string rather than just adjacent or adjacent plus one cells. The circuit uses one capacitor rather than multiple and the cost of scaling up is very reasonable.

A disadvantage which has lead to reduced research into this solution is the very slow overall balancing speed. If only two cells are out of balance then it is very 
quick. However, in reality all cells in a battery pack have variations in SOC after charging or discharging. As this topology only allows one cell to be balanced at a time, with large strings of cells the balancing time becomes unacceptable therefore scalability is an issue [22].

Improvements to this circuit have come in the form of better, or more complicated control methods, rather than circuit configuration. Daowd [23] proposes a control method that alters the duty cycle of the switching based on the voltage difference between upper and lower cells. In his experiment, balancing time was reduced from 33 hours to 19 hours.

\subsubsection{Cuk}

The Cuk converter (figure 4) provides cell to cell equalisation at high efficiency. The energy transfer component is the capacitor and high SOC cells charge up the capacitor while it discharges into adjacent lower SOC cells. Energy is shuttled back and forth until the battery pack is balanced with a very simple 50\% duty cycle on the switches. The inductors are used to keep a constant current to the capacitor while charging and discharging boosting overall efficiency compared to the switched capacitor method. 


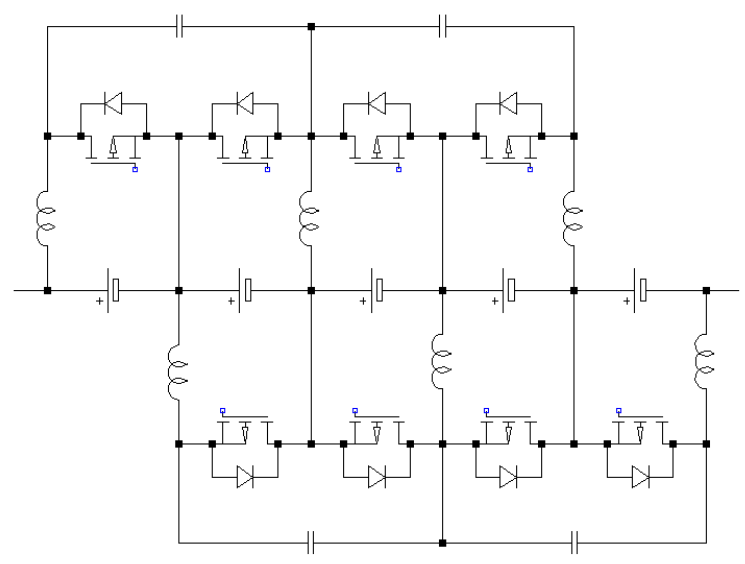

Figure 4: Cuk converter based CEC

The main advantage of this circuit is its high efficiency, low voltage and low current stresses on the switches [15].

Due to the cell to cell nature of balancing, the equalisation speed suffers as a result as energy has to be passed though each cell to balance top and bottom. Due to component number, the cost of the solution is high as well as the volume of the circuit.

$\mathrm{Lu}$ [24] has combined the buck-boost and Cuk converter types managing to reduce the number of switches required from $2 n-2$ to $n$ (with $\mathrm{n}$ denoting the number of cells). It also provides a mechanism to bypass defective cells therefore potentially increasing the life time of the battery pack. This topology remains cell to cell, therefore equalisation speed suffers as more cells are added in series to the string. Although the component number has been reduced it remains relatively expensive and requires a large circuit footprint. Ling [25] suggests an isolated Cuk converter where all cells are connected to an energy bus through isolated capacitors. This converter reaches high efficiency through synchronous switching 
but has the same disadvantages as the traditional Cuk converter.

\subsection{Inductor based CEC}

\subsubsection{Buck-boost}

The basic circuit shown in figure 5 uses inductors rather than capacitors as temporary energy storage. This is a cell to cell equalisation scheme where a cell with a high SOC will be switched in series with an inductor. This charges the inductor until steady current is achieved. The inductor will then discharge to an adjacent cell with a lower SOC [26]. There is no control method required as the circuit operates continuously in two modes: $1^{\text {st }}$ even switches turned on and odd switches are off, $2^{\text {nd }}$ even switches are turned off and all odd switches are turned on.

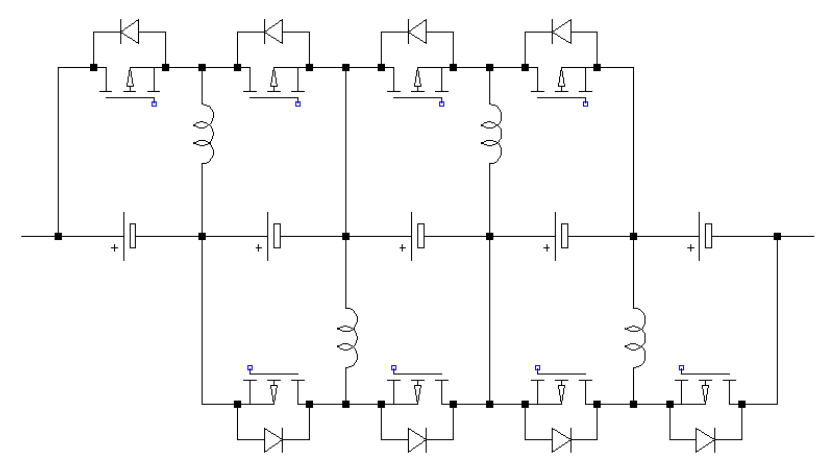

Figure 5: Basic switched inductor CEC

Balancing can occur during both charging and discharging cycles, with no complicated controller needed. This is a cell to cell method, therefore equalisation speed is an issue. Traditionally inductors are more expensive and bulky than capacitors. 
Research's have looked to improve the basic inductor circuit. Moghaddam [27] proposes a tiered inductor circuit allowing non-adjacent cells to balance (although not pack wide). This configuration achieves a balancing time of $0.025 \mathrm{~s}$ with eight cells between 3-3.6V. However, with more inductors and switches this brings increased cost and volume of circuit. Phung [28] introduces a topology based on pulse width modulation (PWM) switching with some capacitive filters for improved current ripple control. He goes on to improve the circuit to include a full bridge configuration of switches with a coupled inductor. Ding [29] presents a modularised version where cells are grouped into threes, boasting reduced equalisation time compared to the basic buck-boost topology.

\subsubsection{Single switched inductor}

The single switched inductor offers direct cell to cell balancing. Operation is very similar to the single switched capacitor.

This circuit requires fewer components, therefore volume of the circuit is kept low. The cost compared to other CECs is also low [30].

However just like the single switched capacitor, the main disadvantage is that when using large strings of series connected cells the equalisation time suffers greatly [27].

\subsubsection{Flyback}

The flyback converter is an isolated version of the single switched inductor. Instead of having a single inductor for energy storage two inductors are coupled providing a primary side for energy storage and a secondary side to provide isolation. Topologies are similar to a single transformer [31] and a multi-winding transformer [32]. 
The flyback structure can provide cell to pack, pack to cell and cell to pack to cell depending on bi-directional switching and control. Efficiency is high and the current and voltage stresses are low.

The main drawbacks, as with the transformer-based circuits are the large volume, cost and control complexity [15].

\subsubsection{Quasi-resonant}

The quasi-resonant converter shares many similarities with the buck-boost. It is a cell to cell equaliser with high efficiency. With the addition of a resonant LC tank to the circuit it allows the converter to achieve zero current switching which reduces the switching losses and EMI (electro-magnetic interference) compared to the buck-boost [33]. A quasi-resonant circiut can be seen in figure 6 .

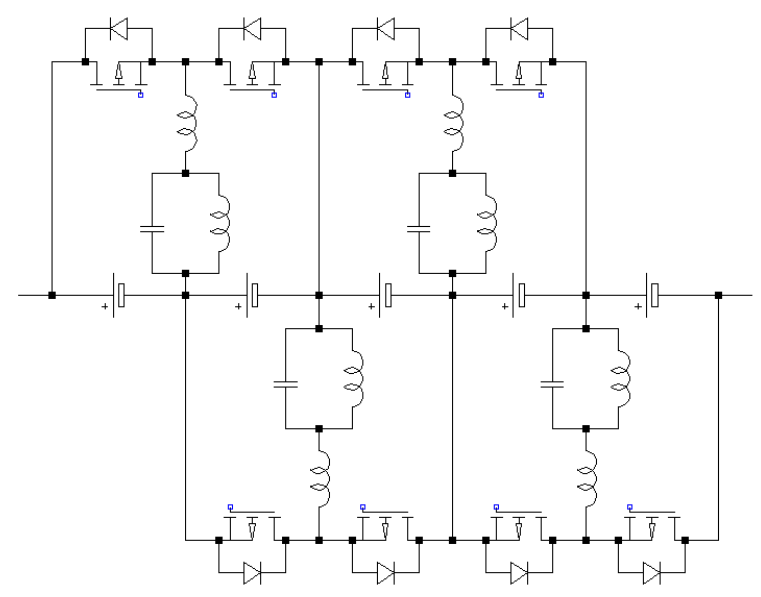

Figure 6: Quasi-resonant CEC

By adding a resonance element into a circuit the component number, and therefore, overall cost of the solution is going to increase as well as the volume of the circuit. Another possible issue is that the control complexity is also increased 
to achieve zero current switching. Additionally, the frequency of switching has to be tuned to the natural resonance frequency of the LC branch [16].

Yuanmao [34] proposes a resonant equaliser without using an additional inductor as the temporary energy storage system. Using the resonant tank itself Yuanmao achieves high efficiency but very long equalisation time. In the simulation provided all components are ideal, he goes on to say that due to additional resistances in a real life setting the LC oscillation would become lightly damped therefore reducing the effectiveness of the circuit. Sung [35] suggests a cell to pack to cell version where there is only one resonant tank that is shared between many cells. This time-shared idea uses the single capacitor style switching to allow any cells to be connected with the energy storage (in this case an LC tank). Again the resonant aspect allows for zero current switching therefore increasing efficiency. Balancing time even for a small string of cells was extremely high. Lee [36] proposes a similar topology with slightly different switch configuration and again has very long equalisation times with so many cells all sharing one LC resonance tank as the energy storage component. Moghaddam [37] modifies a basic single tiered switched capacitor system to incorporate a resonant element. In this scheme a $50 \%$ duty ratio is applied to all odd and even switches. The switching frequency is chosen so it is half the resonant frequency to achieve zero current switch on and off. This decreases equalisation time and increases efficiency compared to the switched capacitor method. Shang [13] uses a LC resonance tank in conjunction with an extensive switching scheme that allows multiple cells to balance multiple cells. This topology boasts very good equalisation speed, efficiency and scalability, however requires $4 n$ switches or relays $(n=$ number of cells) making this circuit very large and expensive. Building on Shang's work, 
Sun [38] presents a double tired modular LC circuit. The circuit focuses on improving equalisation efficiency and time when the voltage difference between two cells is very low.

\subsection{Transformer}

The transformer-based CEC is often very efficient with quick equalisation speeds. The simple topologies are either cell to pack or pack to cell. However, with the use of bidirectional switching and a more complex controller, multicell to multi-cell can be achieved [16]. Transformer-based circuits in general are very expensive and highly complex to control as well as having a large circuit footprint [39].

\subsubsection{Multiple transformer}

In this topology shown in figure 7 each cells has its own dedicated transformer (secondary and primary). This method is said to be cell to pack, when a cell has excess charge switching allows the cells to provide a discharge current into its transformer where the energy is stored within the magnetic field. When the switch is turned off the stored energy is then redistributed into all other connected transformers, and therefore, cells. This iterative process continues until all cells are at the same SOC.

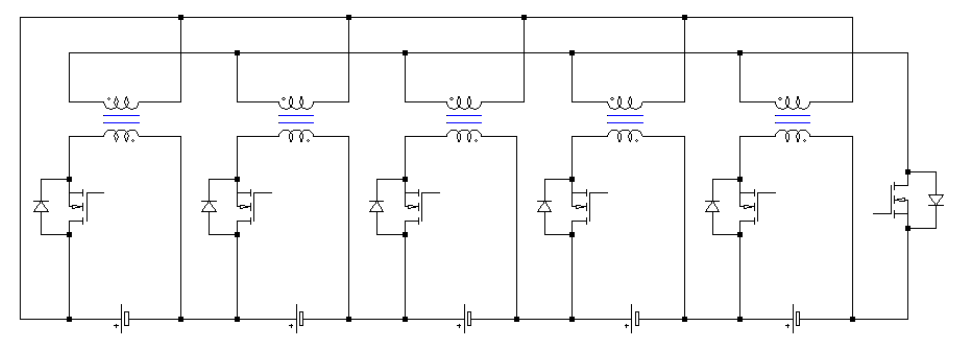

Figure 7: Multiple transformer CEC 
Equalisation is quick and the current and voltage stresses on the switches are very low.

However, as each cell requires its own transformer, the volume and cost of the solution is very high. An improvement of this circuit is the ramp converter which allows one transformer for every two cells. The operation is very similar to the multiple transformer, however, when the energy is going into the pack, half the cycle is dedicated to charging even numbered cells with the other half cycle dedicated to the odd numbered cells [40]. This configuration reduces circuit cost and volume.

\subsubsection{Switched single transformer}

In order to further reduce the costs a single transformer can be utilised with a switching mechanism that is similar to the single switched inductor/capacitor. This can be set up as cell to pack, pack to cell or with bi-directional switches cell to pack to cell. A large number of switches are required for this circuit, with an expensive and large transformer.

This configuration is best utilised in small modules of 8-10 cells within a large battery pack. A coupling capacitor allows each adjacent module to then become balanced.

\subsubsection{Multi-secondary windings transformer}

The last transformer topology is a hybrid of the two previously discussed and the most popular in research. Here the cells have a dedicated secondary winding, however, all share the same primary as can be seen from figure 8 . The transformers themselves, are a subject of much research to improve size, cost and performance. 


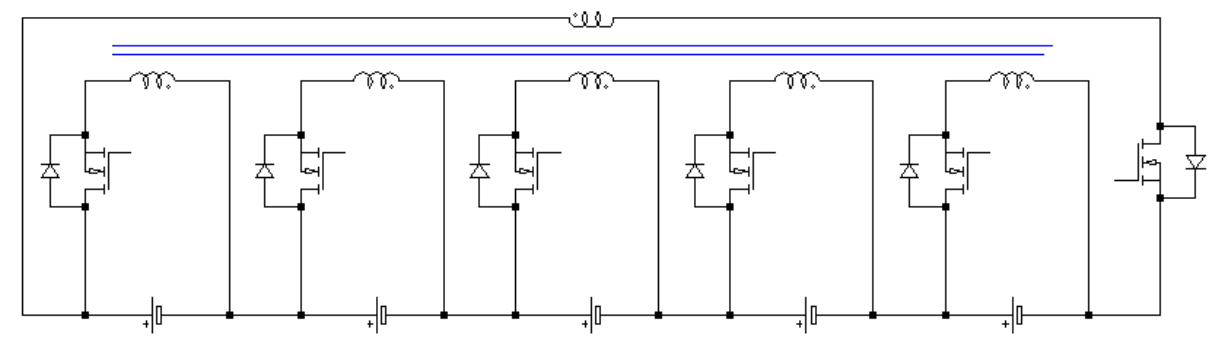

Figure 8: Multi-winding transformer CEC

This configuration reduces the amount of windings compared to the multitransformer circuit, however, a custom made multi-winding transformer is often required. This increases costs dramatically. The transformer ratio is based on the number of cells connected e.g. for eight cells each secondary winding has a ratio of $1 / 8$. Therefore scalability is an issue when considering 96 cells within a series string. This circuit again benefits from a modular design to reduce the cost of the transformer [41, 42].

Moghaddam [43] proposes an improvement to the traditional multi-secondary winding transformer topology by replacing the switch on the primary side by a full bridge switching module. He then indicates that the addition of the full bridge module results in decreased equalisation time with increased efficiency.

\section{Discussion}

A comparison is made of the basic circuits based on a series string of 96 cells. The numbers of switches, resistors, capacitors, inductors, diodes, transformers and multi-winding transforms are shown. Harmonic filter and protection circuits are not taken into account. Judgements on speed, cost, circuit volume and con- 
trol complexity are taken from multiple review papers and individual publications $[15,16,44,45,22,46]$. Efficiency was not taken into account due to all active equalisation circuits reporting efficiencies ranging from $85 \%$ to $97 \%$.

\begin{tabular}{|c|c|c|c|c|c|c|c|c|c|c|c|c|}
\hline \multirow{2}{*}{ CEC type } & \multirow{2}{*}{ Current path } & \multirow{2}{*}{ Speed } & \multicolumn{7}{|c|}{ Components } & \multirow{2}{*}{ Cost } & \multirow{2}{*}{ Circuit Volume } & \multirow{2}{*}{ Control complexity } \\
\hline & & & Switches & $\mathrm{R}$ & $\mathrm{C}$ & $\mathrm{L}$ & Diodes & $\mathrm{T}$ & MWT & & & \\
\hline Switched Capacitor & $\mathrm{AC} 2 \mathrm{C}$ & Slow & 192 & 0 & 95 & 0 & 0 & 0 & 0 & Low & Medium & Easy \\
\hline $\begin{array}{l}\text { Double tiered } \\
\text { switched capacitor }\end{array}$ & $\mathrm{AC} 2 \mathrm{C}$ & Medium & 192 & 0 & 189 & 0 & 0 & 0 & 0 & Medium & Medium & Easy \\
\hline $\begin{array}{l}\text { Single switched } \\
\text { capacitor }\end{array}$ & $\mathrm{DC} 2 \mathrm{C}$ & Slow & 384 & 0 & 1 & 0 & 0 & 0 & 0 & Low & Small & Medium \\
\hline Cuk Converter & $\mathrm{AC} 2 \mathrm{C}$ & Medium & 190 & 0 & 95 & 96 & 0 & 0 & 0 & Medium & Medium & Complex \\
\hline $\begin{array}{l}\text { Buck-Boost } \\
\text { converter }\end{array}$ & $\mathrm{AC} 2 \mathrm{C}$ & Medium & 190 & 0 & 0 & 95 & 0 & 0 & 0 & Medium & Medium & Complex \\
\hline Single inductor & $\mathrm{DC} 2 \mathrm{C}$ & Slow & 194 & 0 & 0 & 1 & 1 & 0 & 0 & Medium & Small & Medium \\
\hline Flyback converter & $\mathrm{DC} 2 \mathrm{C}$ & Slow & 192 & 0 & 0 & 2 & 193 & 0 & 0 & Medium & Large & Complex \\
\hline Quasi-Resonant & $\mathrm{AC} 2 \mathrm{C}$ & Medium & 190 & 0 & 95 & 190 & 0 & 0 & 0 & High & Large & Complex \\
\hline Single transformer & $\mathrm{C} 2 \mathrm{P}$ or $\mathrm{P} 2 \mathrm{C}$ & Slow & 192 & 0 & 0 & 0 & 193 & 1 & 0 & High & Large & Medium \\
\hline $\begin{array}{l}\text { Multi-windings } \\
\text { transformer }\end{array}$ & $\mathrm{C} 2 \mathrm{P}$ or $\mathrm{P} 2 \mathrm{C}$ & Slow & 96 & 0 & 0 & 0 & 1 & 0 & 1 & High & Large & Complex \\
\hline
\end{tabular}

Table 1: Comparison of the basic cell equalisation circuits

Looking at table 1 it can be seen that for a long string of 96 cells the adjacent cell to cell equalisation paths provide slow equalisation times. A tiered or chain structure can improve on this to the detriment of circuit cost and volume. The converter based adjacent cell to cell schemes offer better equalisation speeds than the basic switched capacitor. The direct cell to cell equalisation times are also slow, in the worst case scenario all cells would be out of balance with each other. Due to the time-shared nature of these schemes only one cell can be balanced at a time leading to very slow equalisation. The main advantages of these schemes are that the size and cost of the circuit are usually kept low. Cell to pack or pack to cell equalisation speed varies. In general their speed is quite fast, however the worst case scenario of the cell to pack is that one cell is under-charged compared 
to the rest of the pack. In this case the other 95 cells need to be cycled through systematically in order to balance the pack which would be very slow. In pack to cell topologies one overcharged cell is the worst case scenario, where energy would have to be taken from the pack and redistributed 95 times to the other cells. To improve this bidirectional switches and a more complicated controller can be used to allow the circuit to switch from cell to pack, to pack to cell depending on which situation is needed. It can be seen from table 1 that any circuit that requires transformers or a high amount of inductors are quite costly, whereas the circuits that are based on capacitors are generally cheaper. Following that trend is the volume of the circuits as well, where transformer and inductors take up a lot of space compared to capacitors. One thing, however, that is not covered by any of the review papers is that the thermal characteristics and reliability of inductors are generally better than capacitors, therefore for circuits needing to operate under high temperatures inductors may be the better choice.

The control methods required by the different equalisation circuits ranges from continuous switching with no voltage sensing required (easy control) to a complex control algorithm as proposed by Kim [47].

These control circuits do not take cost or size of circuit into account during these comparisons. However this would obviously impact on both of those qualities.

Moving forward in this field of research there are three suggestions which this paper puts forward. 1) Meaningful comparison, 2) An understanding of what industry requires/deems acceptable for a CEC and 3) Continued prototyping.

To that end for meaningful quantitative comparison to happen a simulation standard has to be developed [48]. With test conditions such as cell model, num- 
ber of cells connected in series and initial values of SOC set with a standard distribution and deviation. This would allow direct and measurable comparison of attributes like equalisation time. Chatzinikolaou, proposes an interesting circuit evaluation tool based on a linear programming problem, however, needs a simplified set of conditions such as constant cell voltage [48].

A large majority of papers report on equalisation speed as its main contribution/upgrade compared to other papers. There is however no context or measuring point on what is an acceptable equalisation speed for $n$ number of cells.

Lastly the inclusion of a prototype to check against real components rather than ideal modals is vital for researchers and industry to build upon that body of work with confidence and enabling the reproduction of results as long as equipment used is specified.

\section{Future research opportunities}

In this section three areas are highlighted that could provide possible improvements to the charge balancing problem. Wide band gap semi-conductors are new power switches that could improve existing circuits by reducing the volume and cost of passive components, while increasing efficiency and thermal characteristics. Integrating a CEC within the level 1/2 on-board charger offers possible reduction in costs due to component sharing. Finally re-configurable batteries offer complete flexibility in terms of power delivered/required, and additional can be used to equalise charge between cells.

\subsection{Using wide band gap semi-conductors}

Wide band gap (WBG) devices refer to any power electronic switch primarily made with a wide band gap material such as $\mathrm{SiC}$ (silicon carbide) or $\mathrm{GaN}$ (Gallium 
Nitride) [49]. The wide band gap aspect to these materials denoted that they have a large eV gap between their valence and conducting bands. Table 5.1 shows values of band gaps for various semi-conductors with a WBG material having an energy gap higher than $3 \mathrm{eV}[50]$.

\begin{tabular}{|l|c|c|}
\hline \multicolumn{3}{|l|}{ Semiconductor materials } \\
\hline Material & Chemical symbol & Band gap energy (eV) \\
\hline Germanium & $\mathrm{Ge}$ & 0.7 \\
\hline Silicon & $\mathrm{Si}$ & 1.1 \\
\hline $\begin{array}{l}\text { Gallium } \\
\text { Arsenide }\end{array}$ & $\mathrm{GaAs}$ & 1.4 \\
\hline $\begin{array}{l}\text { Silicon } \\
\text { Carbide }\end{array}$ & $\mathrm{SiC}$ & 3.3 \\
\hline Zinc Oxide & $\mathrm{ZnO}$ & 3.4 \\
\hline $\begin{array}{l}\text { Gallium } \\
\text { Nitride }\end{array}$ & $\mathrm{GaN}$ & 3.4 \\
\hline Diamond & $\mathrm{C}$ & 5.5 \\
\hline
\end{tabular}

Table 2: Band gap energy levels for various semi-conducting materials

From the list of semi-conductors silicon has been widely used as the main material for power switches such as: power diodes, thyristors, metal-oxide semiconductor field effect transistor (MOSFET) and insulated gate bi-polar transistors (IGBT's) [51]. It is a well-researched and mature technology that is at the limits of its potential to be used as high voltage, high frequency switching in modern power electronics [52]. Of the WBG materials $\mathrm{SiC}$ and $\mathrm{GaN}$ are the most mature technologies giving a balance of good material characteristics and economic viability. 
A wide band gap is directly related to the electric field critical breakdown $E_{c}$. $E_{c}$ measured in $V \cdot \mu m^{-1}$ determines the reverse breakdown voltage of the device relative to the thickness. Si has an $E_{c}=20 V \cdot \mu m^{-1}$ whereas $\mathrm{SiC}$ and $\mathrm{GaN}$ have an $E_{c} \approx 300 V \cdot \mu m^{-1}$ [53]. This means for the same voltage rating WBG devices can be a lot smaller, or for the same size the voltage rating of a WBG semiconductor can be a lot higher $[54,50]$.

Another advantage is the thermal conductivity of WBG switches compared to silicon. When the device is on-state and current is flowing through the device one of the limiting factors is the amount of heat produced [52] as seen from diagrams shown in Millan, Huang, Han and Jones[55, 53, 50, 56]. This needs to be kept below a material property threshold for the device to work within expected parameters. Current rating is determined by the current density $\mathrm{J}$ that can be achieved by the device and the area of the device in question [53].

$$
I=J \cdot A_{\text {chip }}
$$

$$
\begin{aligned}
& I=\text { current }(A) \\
& J=\text { current density }\left(A . \mathrm{cm}^{-2}\right) \\
& A=\text { area of the chip }\left(\mathrm{cm}^{2}\right)
\end{aligned}
$$

For MOSFETS and IGBT's respectfully calculating current density of the device follows the equations [53]:

$$
\begin{gathered}
J_{\text {Ohmic.IV }}=\sqrt{\frac{T_{\text {jmax }}-T_{\text {case }}}{R_{j c-s p} \times R_{\text {on-sp }}}} \\
J_{\text {non-Ohmic.IV }}=\frac{T_{j m a x}-T_{\text {case }}}{R_{j c-s p} \times V_{F}}
\end{gathered}
$$


$T_{\text {jmax }}=$ Maximum junction temperature $\left({ }^{o} \mathrm{c}\right)$

$T_{\text {case }}=$ Case temperature of the device $\left({ }^{\circ} \mathrm{c}\right)$

$R_{j c-s p}=$ S pecific thermal resistance from junction to case $\left({ }^{o} \mathrm{c} . \mathrm{cm}^{2} / W\right)$

$R_{\text {on-sp }}=$ S pecific on resistance $\left(\Omega / \mathrm{cm}^{2}\right)$

$V_{F}=$ On - state forward voltage drop $(V)$

Analysing the equations shows that an increased $T_{\text {jmax }}$ and a low $R_{o n-s p}$ or $V_{F}$ gives a rise to the current density, in turn this means that potential chip size can be reduced and therefore potential price of the chip is also reduced. SiC has great potential for very high operating temperatures whereas due to the high $E_{c}$ and electron mobility of $\mathrm{GaN}$ the low on-state losses are what primarily contribute to its high electron density [50]. For both materials packaging is extremely important to optimise efficiency and to really extract the full potential out of the materials.

Both $\mathrm{GaN}$ and $\mathrm{SiC}$ materials have the ability for very high frequency operation $>100 \mathrm{MHz}$ without excessive power loss compared to $\mathrm{Si}$. This is an advantage for any circuit with magnetic components as the size of inductors and transformers can therefore be reduced. EMI (electro-magnetic interference) has to be monitored closely, however, so circuit design is extremely important.

In summary both $\mathrm{GaN}$ and $\mathrm{SiC}$ exhibit very good material properties compared to Si due to properties such as energy band gap, critical electric field, thermal conductivity and electron mobility. However, in the context of cell equalisation circuits $\mathrm{GaN}$ switches offer better potential performance than SiC. While the more mature SiC offers higher temperature operation and higher blocking voltages [57]. GaN boasts smaller switching losses, lower on-resistances and faster switching due to its better electron mobility and zero reverse recovery charge [49]. This means low loss high frequency switching can be achieved, which should re- 
duce the size and increase the thermal capabilities of the equalisation circuits. Evaluating which topologies benefit the most from GaN power devices and conducting a comparison of how much performance increases is a potential direction for research.

\subsection{Integration of CEC with EV Charger}

In the case of integrating the charge equalisation circuit with the EV charger, intelligent switching removes cells on an individual basis from the charging process. This is an improvement over the concept of stopping the charging process when one cell is said to have reached its threshold. Rather, the cells that reach the threshold are removed, the charging process continues until all cells have reached the threshold, therefore all cells are balanced when fully charged. Full bridge or half bridge switching can be added to each cell to achieve this [58, 59]. Hong [60] proposes using a bi-directional DC-DC converter for each cell so balancing can occur through charging and discharging cycles. Tashakor goes into detail about the complex controllers needed for each charging stage in the circuit topology suggested in [61]. Ramesh [62], uses a dual active bridge (DAB) converter as the main tool to balance the series-connected cells during charging. Ramesh also suggests an interleaved phase shift controller to reduce the complexity and computational power required by the battery management system.

The main disadvantage of the integrated CEC is that balancing will only occur when using level 1 or 2 charging. Fast level 3 charging requires off-board high voltage converters that directly connect to the battery, which would bypass the integrated equalisation circuit.

All of the systems proposed above use a switching layer connected to the cells to implement the cell selection. As other components, for example, additional 
transformers, inductors and capacitors are not required, the cost of the integrated CEC is not as high as the transformer-based circuits. Every electric vehicle has on board circuitry allowing the car to be charged either by level 1 or level 2 connections. Providing a cheap and easy method where the charging circuitry and a charge equaliser are together is a challenge, but it has the potential to reduce costs compared to a dedicated CEC.

\subsection{Re-configurable batteries}

Battery reconfiguration offers more opportunities and is more advanced than just cell skipping during charging and discharging, although this feature is still exploitable. By re-configuring the battery pack the number of series and parallel connections are changed. Instead of charging a series string of 12 cells, risking imbalance, the pack could be re-configured to 12 cells connected in parallel. Charging a parallel module of 12 cells negates that possibility. He [63] suggests that online reconfiguration (reconfiguration during battery discharge) is theoretically possible, however impractical. He then explains that cell reconfiguration should only be done off line (when the pack is idle) to limit the safety risks such as a high arcing current.

For a battery pack to be completely re-configurable a large number of switches is required as well as a complex control methodology. Cell equalisation can only occur during extending charging sessions with pack configuration happening before and then returned to normal after charging at the moment. There are opportunities to overcome or build protection so an on-line re-configurable battery pack can be realised.

Ditsworth [64] proposes a switching topology designed to reduce the total number of switches required while still maintaining a good amount of control 
over cell configurations. However, there are lots more possibilities for research in this area.

\section{Conclusion}

Li-ion battery packs are being used more and more to power electric vehicles and provide energy storage either at home or grid side. The issue of cell balancing is a vital aspect to allow continued good heath and capacity of the battery pack for as long as possible. The properties required for the perfect solution are highlighted. This paper attempts to provide an overview of the research that is being conducted in this field. Both passive and active cell balancing solutions are analysed with the active solutions broken up into capacitor, inductor or transformerbased. Each basic circuit is presented with the main advantages and disadvantages highlighted and notable variations discussed.

A comparison is made, and then the problems associated with making meaningful comparisons are discussed. A solution is presented that the simulation process which every new charge equalisation circuit or scheme starts as, becomes standardised among the researchers in this field.

Finally, future research is considered using modern components to improve existing solutions. Integrating existing solutions within the charging circuitry allow both circuits to share resources and lower costs. And lastly, providing a fully

flexible battery pack that can be reconfigured for different voltage and current requirements. 


\section{Acknowledgement}

This work is partly supported by the SEND project (grant ref. 32R16P00706) funded by ERDF and BEIS. We would also like to thank Add2 Ltd for their continued support and technical expertise during this project. 
[1] M. S. H. Lipu, M. A. Hannan, A. Hussain, M. M. Hoque, P. J. Ker, M. H. M. Saad, and A. Ayob, "A review of state of health and remaining useful life estimation methods for lithium-ion battery in electric vehicles: Challenges and recommendations," Journal of Cleaner Production, vol. 205, pp. 115133, Dec. 2018.

[2] D. Stroe, M. Swierczynski, S. K. Kær, and R. Teodorescu, "Degradation Behavior of Lithium-Ion Batteries During Calendar Ageing-The Case of the Internal Resistance Increase," IEEE Transactions on Industry Applications, vol. 54, pp. 517-525, Jan. 2018.

[3] D. Belov and M.-H. Yang, "Failure mechanism of Li-ion battery at overcharge conditions," Journal of Solid State Electrochemistry, vol. 12, pp. 885894, Aug. 2008.

[4] H. Maleki and J. N. Howard, "Effects of overdischarge on performance and thermal stability of a Li-ion cell," Journal of Power Sources, vol. 160, pp. $1395-1402$, Oct. 2006.

[5] R. Guo, L. Lu, M. Ouyang, and X. Feng, "Mechanism of the entire overdischarge process and overdischarge-induced internal short circuit in lithiumion batteries," Scientific Reports, vol. 6, p. 30248, July 2016.

[6] M. J. Isaacson, R. P. Hollandsworth, P. J. Giampaoli, F. A. Linkowsky, A. Salim, and V. L. Teofilo, "Advanced lithium ion battery charger," in Fifteenth Annual Battery Conference on Applications and Advances (Cat. No.00TH8490), pp. 193-198, Jan. 2000. 
[7] J. Xu, X. Mei, and J. Wang, "A High Power Low-Cost Balancing System for Battery Strings," Energy Procedia, vol. 158, pp. 2948-2953, Feb. 2019.

[8] M. Daowd, N. Omar, P. V. D. Bossche, and J. V. Mierlo, "Passive and active battery balancing comparison based on MATLAB simulation," in 2011 IEEE Vehicle Power and Propulsion Conference, pp. 1-7, Sept. 2011.

[9] S. R. D. Santos, J. P. V. Fracarolli, A. Y. M. Narita, J. C. M. S. Aranha, F. L. R. Marques, J. C. Sansão, and P. V. B. Hamacek, “Dissipative LithiumIon Cell Balancing by Recharge Control and Detection of Outliers for Energy Optimization and Heat Reduction," in IECON 2018 - 44th Annual Conference of the IEEE Industrial Electronics Society, pp. 5038-5043, Oct. 2018.

[10] T. A. Stuart and W. Zhu, "Fast equalization for large lithium ion batteries," IEEE Aerospace and Electronic Systems Magazine, vol. 24, pp. 27-31, July 2009.

[11] W. Diao, N. Xue, V. Bhattacharjee, J. Jiang, O. Karabasoglu, and M. Pecht, "Active battery cell equalization based on residual available energy maximization," Applied Energy, vol. 210, pp. 690-698, Jan. 2018.

[12] X. Liu, K. Li, Z. Sun, and Q. Liu, “An Active Equalization Circuit Based on the Share Bus for series Li-Ion Battery,' in 2018 IEEE 3rd Advanced Information Technology, Electronic and Automation Control Conference (IAEAC), pp. 2450-2454, Oct. 2018.

[13] Y. Shang, Q. Zhang, N. Cui, B. Duan, Z. Zhou, and C. Zhang, "Multi-Cellto-Multi-Cell Equalizers Based on Matrix and Half-Bridge LC Converters 
for Series-Connected Battery Strings," IEEE Journal of Emerging and Selected Topics in Power Electronics, pp. 1-1, 2019.

[14] C. Pascual and P. T. Krein, "Switched capacitor system for automatic series battery equalization," in Proceedings of APEC 97 - Applied Power Electronics Conference, vol. 2, pp. 848-854 vol.2, Feb. 1997.

[15] M. M. Hoque, M. A. Hannan, A. Mohamed, and A. Ayob, "Battery charge equalization controller in electric vehicle applications: A review," Renewable and Sustainable Energy Reviews, vol. 75, pp. 1363-1385, Aug. 2017.

[16] J. Gallardo-Lozano, E. Romero-Cadaval, M. I. Milanes-Montero, and M. A. Guerrero-Martinez, "Battery equalization active methods," Journal of Power Sources, vol. 246, pp. 934-949, Jan. 2014.

[17] Y. Ye, K. W. E. Cheng, Y. C. Fong, X. Xue, and J. Lin, “Topology, Modeling, and Design of Switched-Capacitor-Based Cell Balancing Systems and Their Balancing Exploration," IEEE Transactions on Power Electronics, vol. 32, pp. 4444-4454, June 2017.

[18] M. Kim, C. Kim, J. Kim, and G. Moon, "A Chain Structure of Switched Capacitor for Improved Cell Balancing Speed of Lithium-Ion Batteries," IEEE Transactions on Industrial Electronics, vol. 61, pp. 3989-3999, Aug. 2014.

[19] Y. Shang, Q. Zhang, N. Cui, B. Duan, and C. Zhang, "An Optimized MeshStructured Switched-Capacitor Equalizer for Lithium-Ion Battery Strings," IEEE Transactions on Transportation Electrification, pp. 1-1, 2018. 
[20] A. C. Baughman and M. Ferdowsi, "Double-Tiered Switched-Capacitor Battery Charge Equalization Technique," IEEE Transactions on Industrial Electronics, vol. 55, pp. 2277-2285, June 2008.

[21] R. Fukui and H. Koizumi, "Double-tiered switched capacitor battery charge equalizer with chain structure," in IECON 2013 - 39th Annual Conference of the IEEE Industrial Electronics Society, pp. 6715-6720, Nov. 2013.

[22] J. Cao, N. Schofield, and A. Emadi, "Battery balancing methods: A comprehensive review," in 2008 IEEE Vehicle Power and Propulsion Conference, pp. 1-6, Sept. 2008.

[23] M. Daowd, M. Antoine, N. Omar, P. v. Den Bossche, and J. Van Mierlo, "Single Switched Capacitor Battery Balancing System Enhancements," Energies (19961073), vol. 6, pp. 2149-2174, Apr. 2013.

[24] X. Lu, W. Qian, and F. Z. Peng, "Modularized buck-boost + Cuk converter for high voltage series connected battery cells," in 2012 Twenty-Seventh Annual IEEE Applied Power Electronics Conference and Exposition (APEC), pp. 2272-2278, Feb. 2012.

[25] R. Ling, Q. Dan, L. Wang, and D. Li, "Energy bus-based equalization scheme with bi-directional isolated Cuk equalizer for series connected battery strings," in 2015 IEEE Applied Power Electronics Conference and Exposition (APEC), pp. 3335-3340, Mar. 2015.

[26] D. Peng, M. Yan, C. Yang, Z. Fan, and C. Hong, "Equalization of series connected Lithium-ion battery based on state of charge in Electric Vehicle," in 
2018 13th World Congress on Intelligent Control and Automation (WCICA), pp. 310-315, July 2018.

[27] A. F. Moghaddam and A. V. D. Bossche, "An Active Cell Equalization Technique for Lithium Ion Batteries Based on Inductor Balancing," in 2018 9th International Conference on Mechanical and Aerospace Engineering (ICMAE), pp. 274-278, July 2018.

[28] T. H. Phung, J. Crebier, A. Chureau, A. Collet, and V. Nguyen, "Optimized structure for next-to-next balancing of series-connected lithium-ion cells," in 2011 Twenty-Sixth Annual IEEE Applied Power Electronics Conference and Exposition (APEC), pp. 1374-1381, Mar. 2011.

[29] X. Ding and D. Zhang, "A Novel Active Equalization Topology for SeriesConnected Lithium-ion Battery Packs," in 2018 IEEE Energy Conversion Congress and Exposition (ECCE), pp. 2753-2758, Sept. 2018.

[30] S. Park, T. Kim, J. Park, G. Moon, and M. Yoon, "A New Buck-boost Type Battery Equalizer," in 2009 Twenty-Fourth Annual IEEE Applied Power Electronics Conference and Exposition, pp. 1246-1250, Feb. 2009.

[31] J. Shin, G. Seo, C. Chun, and B. Cho, "Selective flyback balancing circuit with improved balancing speed for series connected Lithium-ion batteries," in The 2010 International Power Electronics Conference - ECCE ASIA -, pp. 1180-1184, June 2010.

[32] W. XueZhe, Z. Xiaopeng, and H. Dai, "The application of flyback DC/DC converter in Li-ion batteries active balancing," in 2009 IEEE Vehicle Power and Propulsion Conference, pp. 1654-1656, Sept. 2009. 
[33] Y. Lee and G. Cheng, "Quasi-Resonant Zero-Current-Switching Bidirectional Converter for Battery Equalization Applications," IEEE Transactions on Power Electronics, vol. 21, pp. 1213-1224, Sept. 2006.

[34] Y. Yuanmao, K. W. E. Cheng, and Y. P. B. Yeung, "Zero-Current Switching Switched-Capacitor Zero-Voltage-Gap Automatic Equalization System for Series Battery String," IEEE Transactions on Power Electronics, vol. 27, pp. 3234-3242, July 2012.

[35] C.-h. Sung, K. Lee, and B. Kang, "Voltage equalizer for li-ion battery string using LC series resonance," in IECON 2013 - 39th Annual Conference of the IEEE Industrial Electronics Society, pp. 1404-1409, Nov. 2013.

[36] K. Lee, Y. Chung, C. Sung, and B. Kang, "Active Cell Balancing of Li-Ion Batteries Using\$LC\$Series Resonant Circuit," IEEE Transactions on Industrial Electronics, vol. 62, pp. 5491-5501, Sept. 2015.

[37] A. F. Moghaddam and A. V. d. Bossche, "A Cell Equalization Method Based on Resonant Switched Capacitor Balancing for Lithium Ion Batteries," in 2018 9th International Conference on Mechanical and Aerospace Engineering (ICMAE), pp. 337-341, July 2018.

[38] X. Sun, L. Zhu, P. Zhang, and M. Lin, "Design of active equalizer for lithium-ion battery pack based on double-tiered modular resonance," Systems Science $\mathcal{E}$ Control Engineering, vol. 6, pp. 314-323, Sept. 2018.

[39] M. Uno, K. Yoshino, and K. Hasegawa, "Direct Cell-to-Cell Voltage Equalizer Using Capacitively-Isolated Parallel-Resonant Converter for SeriesConnected Energy Storage Cells," in 2018 IEEE 18th International Power 
Electronics and Motion Control Conference (PEMC), pp. 94-100, Aug. 2018.

[40] T. Gottwald, Z. Ye, and T. Stuart, "Equalization of EV and HEV batteries with a ramp converter," IEEE Transactions on Aerospace and Electronic Systems, vol. 33, pp. 307-312, Jan. 1997.

[41] T. M. Bui, C.-H. Kim, K.-H. Kim, and S. B. Rhee, "A Modular Cell Balancer Based on Multi-Winding Transformer and Switched-Capacitor Circuits for a Series-Connected Battery String in Electric Vehicles,” Applied Sciences, vol. 8, p. 1278, Aug. 2018.

[42] Y. Li, J. Xu, X. Mei, and J. Wang, "A Unitized Multiwinding Transformer Based Equalization Method for Series-Connected Battery Strings," IEEE Transactions on Power Electronics, pp. 1-1, 2019.

[43] A. F. Moghaddam and A. V. d. Bossche, "Multi-Winding Equalization Technique for Lithium Ion Batteries for Electrical Vehicles," in 2018 7th International Conference on Renewable Energy Research and Applications (ICRERA), pp. 139-143, Oct. 2018.

[44] M. Caspar, T. Eiler, and S. Hohmann, "Comparison of Active Battery Balancing Systems," in 2014 IEEE Vehicle Power and Propulsion Conference (VPPC), pp. 1-8, Oct. 2014.

[45] F. Baronti, R. Roncella, and R. Saletti, "Performance comparison of active balancing techniques for lithium-ion batteries," Journal of Power Sources, vol. 267, pp. 603-609, Dec. 2014. 
[46] W. C. Lee, D. Drury, and P. Mellor, "Comparison of passive cell balancing and active cell balancing for automotive batteries," in 2011 IEEE Vehicle Power and Propulsion Conference, pp. 1-7, Sept. 2011.

[47] C. Kim, M. Kim, and G. Moon, "A Modularized Charge Equalizer Using a Battery Monitoring IC for Series-Connected Li-Ion Battery Strings in Electric Vehicles," IEEE Transactions on Power Electronics, vol. 28, pp. 3779_ 3787, Aug. 2013.

[48] E. Chatzinikolaou and D. J. Rogers, "Performance Evaluation of Duty Cycle Balancing in Power Electronics Enhanced Battery Packs Compared to Conventional Energy Redistribution Balancing," IEEE Transactions on Power Electronics, vol. 33, pp. 9142-9153, Nov. 2018.

[49] A. S. Abdelrahman, Z. Erdem, Y. Attia, and M. Z. Youssef, "Wide Bandgap Devices in Electric Vehicle Converters: A Performance Survey," Canadian Journal of Electrical and Computer Engineering, vol. 41, no. 1, pp. 45-54, 2018.

[50] D. Han, S. Li, W. Lee, and B. Sarlioglu, "Adoption of wide bandgap technology in hybrid/electric vehicles-opportunities and challenges," in 2017 IEEE Transportation Electrification Conference and Expo (ITEC), pp. 561-566, June 2017.

[51] H. Amano, Y. Baines, E. Beam, M. Borga, T. Bouchet, P. R. Chalker, M. Charles, K. J. Chen, N. Chowdhury, R. Chu, C. De Santi, M. M. De Souza, S. Decoutere, L. Di Cioccio, B. Eckardt, T. Egawa, P. Fay, J. J. Freedsman, L. Guido, O. Häberlen, G. Haynes, T. Heckel, D. Hemaku- 
mara, P. Houston, J. Hu, M. Hua, Q. Huang, A. Huang, S. Jiang, H. Kawai, D. Kinzer, M. Kuball, A. Kumar, K. B. Lee, X. Li, D. Marcon, M. März, R. McCarthy, G. Meneghesso, M. Meneghini, E. Morvan, A. Nakajima, E. M. S. Narayanan, S. Oliver, T. Palacios, D. Piedra, M. Plissonnier, R. Reddy, M. Sun, I. Thayne, A. Torres, N. Trivellin, V. Unni, M. J. Uren, M. Van Hove, D. J. Wallis, J. Wang, J. Xie, S. Yagi, S. Yang, C. Youtsey, R. Yu, E. Zanoni, S. Zeltner, and Y. Zhang, "The $2018 \mathrm{GaN}$ power electronics roadmap," Journal of Physics D: Applied Physics, vol. 51, p. 163001, Apr. 2018.

[52] F. Roccaforte, P. Fiorenza, G. Greco, R. L. Nigro, F. Giannazzo, A. Patti, and M. Saggio, "Challenges for energy efficient wide band gap semiconductor power devices," physica status solidi (a), vol. 211, pp. 2063-2071, Sept. 2014.

[53] A. Q. Huang, "Power Semiconductor Devices for Smart Grid and Renewable Energy Systems," Proceedings of the IEEE, vol. 105, pp. 2019-2047, Nov. 2017.

[54] R. Singh, J. A. Cooper, M. R. Melloch, T. P. Chow, and J. W. Palmour, "SiC power Schottky and PiN diodes," IEEE Transactions on Electron Devices, vol. 49, pp. 665-672, Apr. 2002.

[55] J. Millán, P. Godignon, X. Perpiñà, A. Pérez-Tomás, and J. Rebollo, "A Survey of Wide Bandgap Power Semiconductor Devices," IEEE Transactions on Power Electronics, vol. 29, pp. 2155-2163, May 2014.

[56] E. A. Jones, F. F. Wang, and D. Costinett, "Review of Commercial GaN 
Power Devices and GaN-Based Converter Design Challenges," IEEE Journal of Emerging and Selected Topics in Power Electronics, vol. 4, pp. 707719, Sept. 2016.

[57] X. She, A. Q. Huang, Lucía, and B. Ozpineci, "Review of Silicon Carbide Power Devices and Their Applications," IEEE Transactions on Industrial Electronics, vol. 64, pp. 8193-8205, Oct. 2017.

[58] L. A. Tolbert, a. T. Cunnyngham, and J. N. Chiasson, "Charge balance control schemes for cascade multilevel converter in hybrid electric vehicles," IEEE Transactions on Industrial Electronics, vol. 49, pp. 1058-1064, Oct. 2002.

[59] Z. Zheng, K. Wang, L. Xu, and Y. Li, "A Hybrid Cascaded Multilevel Converter for Battery Energy Management Applied in Electric Vehicles," IEEE Transactions on Power Electronics, vol. 29, pp. 3537-3546, July 2014.

[60] W. Hong, K. Ng, J. Hu, and C. Moo, "Charge equalization of battery power modules in series," in The 2010 International Power Electronics Conference - ECCE ASIA -, pp. 1568-1572, June 2010.

[61] N. Tashakor, E. Farjah, and T. Ghanbari, "A Bidirectional Battery Charger With Modular Integrated Charge Equalization Circuit," IEEE Transactions on Power Electronics, vol. 32, pp. 2133-2145, Mar. 2017.

[62] P. Ramesh and A. Patra, "Interleaved Phase-Shift Control of a Single Input Multi Output Cell Balancing Circuit using a Dual Active Bridge Configuration," in 2018 IEEE Energy Conversion Congress and Exposition (ECCE), pp. 2726-2733, Sept. 2018. 
[63] L. He, E. Kim, and K. G. Shin, "A Case Study on Improving Capacity Delivery of Battery Packs via Reconfiguration," ACM Trans. Cyber-Phys. Syst., vol. 1, pp. 11:1-11:23, Feb. 2017.

[64] M. Ditsworth and S. Yurkovich, "A Battery Pack Reconfiguration Scheme for Improved Charge Balancing," in 2018 Annual American Control Conference (ACC), pp. 2282-2287, June 2018. 